\title{
Million Copies per Milliliter
}

National Cancer Institute

\section{Source}

National Cancer Institute. Million Copies per Milliliter. NCI Thesaurus. Code C100898.

The unit of concentration expressed as the number of 10 to the sixth power copies in unit volume equal to one milliliter. 